\title{
BMJ Open Standardised tobacco packaging: a health policy case study of corporate conflict expansion and adaptation
}

\author{
Jenny L Hatchard, ${ }^{1}$ Gary J Fooks, ${ }^{2}$ Anna B Gilmore ${ }^{1}$
}

To cite: Hatchard JL, Fooks GJ, Gilmore AB. Standardised tobacco packaging: a health policy case study of corporate conflict expansion and adaptation. BMJ Open 2016;6:e012634. doi:10.1136/bmjopen-2016012634

- Prepublication history and additional material is available. To view please visit the journal (http://dx.doi.org/ 10.1136/bmjopen-2016012634)

Received 13 May 2016 Revised 11 August 2016 Accepted 24 August 2016

CrossMark

\begin{abstract}
${ }^{1}$ Tobacco Control Research Group, Department for Health, University of Bath, Bath, UK

${ }^{2}$ School of Languages and Social Sciences, Aston University, Birmingham, UK
\end{abstract}

Correspondence to Dr Jenny L Hatchard; j.hatchard@bath.ac.uk

\section{ABSTRACT}

Objectives: To investigate opposition to standardised tobacco packaging in the UK. To increase understanding of how transnational corporations are adapting to changes in their access to policymakers precipitated by Article 5.3 of the Framework Convention on Tobacco Control (FCTC).

Design: Case study web-based documentary analysis, using NVivo V.10. Examination of relationships between opponents of standardised packaging and transnational tobacco companies (TTCs) and of the volume, nature, transparency and timing of their activities.

Setting: UK standardised packaging policy debate 2011-2013.

Participants: Organisations selected on basis of opposition to, or facilitation thereof, standardised tobacco packaging in the UK; 422 associated documents.

Results: Excluding tobacco manufacturing and packaging companies ( $n=12), 109$ organisations were involved in opposing standardised packaging, 82 (75\%) of which had a financial relationship with 1 or more TTC. These 82 organisations (43 actively opposing the measure, 39 facilitating opposition) were responsible for $60 \%$ of the 404 activities identified, including the majority of public communications and research production. TTCs were directly responsible for $28 \%$ of total activities, predominantly direct lobbying, but also financially underwrote third party research, communication, mass recruitment and lobbying. Active organisations rarely reported any financial relationship with TTCs when undertaking opposition activities.

Conclusions: The multifaceted opposition to standardised packaging was primarily undertaken by third parties with financial relationships with major tobacco manufacturers. Low levels of transparency regarding these links created a misleading impression of diverse and widespread opposition. Countries should strengthen implementation of Article 5.3 of the FCTC by systematically requiring conflict of interest declarations from all organisations participating in political or media debates on tobacco control.

\section{INTRODUCTION}

On National No Smoking Day, 11 March 2015 , over 6 years after it was first proposed ${ }^{1}$ and following its inclusion in numerous

\section{Strengths and limitations of this study}

- This paper is the first study to systematically examine the scale and nature of opposition to standardised tobacco packaging outside Australia.

- While tobacco industry document research has been used extensively to examine the historical political activity of corporations, this study employs an innovative combination of publicly available sources and investigative research techniques to analyse corporate political action in contemporary health policy conflicts.

- The study presents a novel classification system for systematically examining the sector and relationships of ostensibly distinct organisations opposing public health policy which can be applied in other settings.

- The ongoing nature of the conflict during the study period restricted the study to examining political activity, rather than influence.

- Further research using social network and social media analysis would provide deeper insights into how protobacco policy networks are formed and operate.

policy initiatives, ${ }^{2-4}$ the UK House of Commons voted to introduce standardised packaging for tobacco products (see online supplementary file 1). ${ }^{5}{ }^{6}$ In jurisdictions with advertising $^{7-9}$ and point of sale display restrictions, ${ }^{10-13}$ packaging is (alongside product design) one of transnational tobacco companies' (TTCs) few remaining forms of brand marketing and identity. ${ }^{14-17}$ By prohibiting logos, brand imagery and promotional text, standardised packaging aims to reduce the appeal of tobacco products and increase the effectiveness of health warnings. ${ }^{18-25}$ Academic and government reviews of the evidence have concluded that the policy is likely to reduce youth smoking uptake. ${ }^{18} 26-34$

Standardised packaging is the second major policy restricting tobacco companies' commercial activities (the first being the Point of Sale Display Ban) to be proposed in the UK following the introduction of both 
restrictions on tobacco industry political activity under Article 5.3 of the Framework Convention on Tobacco Control (FCTC) ${ }^{23536}$ and policy instruments associated with the Better Regulation agenda. ${ }^{37-40}$

Article 5.3 of the FCTC requires governments to 'protect' tobacco control policies 'from commercial and other vested interests of the tobacco industry. ${ }^{35}{ }^{36} \mathrm{In}$ order to meet this requirement, the UK Government committed to placing significant restrictions on tobacco companies' capacity to use 'insider' political strategies, such as direct lobbying, to influence tobacco policy. ${ }^{41} 42$ Insider strategies are characterised by a close relationship with policy élites and are based on exchange of information and mutual trust and support. ${ }^{42}$ In response to Article 5.3, the government undertook to publish the details of all policy-related meetings between the tobacco industry and government departments and to require organisations engaging with the Department of Health on tobacco control to disclose any relevant relationship with the industry. ${ }^{3}$ These changes work to formalise tobacco manufacturers' status as political 'outsiders'. ${ }^{5}$

In contrast, reforms under the Better Regulation agenda require that all new policy proposals undergo both stakeholder consultation and impact assessment, for which submissions and data from industry are specifically invited. ${ }^{43-46}$ This creates a new, highly accessible, evidencefocused policymaking venue, into which business and civil society actors can feed information. ${ }^{4043478}$

This study is the first to explore how major tobacco manufacturers are negotiating this new institutional context in the UK. It is also the first European study to examine their political action in response to standardised tobacco packaging proposals, a policy which was first implemented in Australia in 2012 and is being taken up by other jurisdictions (eg, Belgium, Bulgaria, Finland, France, Hungary, Ireland, Norway, Sweden, Canada and New Zealand). Using an innovative approach to tobacco industry research, the study analyses publicly available sources to explore contemporary, rather than historical, ${ }^{49}$ political activity. It aims to identify relationships between TTCs and those opposing standardised packaging and to examine the volume and nature (type and range) of activities undertaken by them to oppose the policy in the UK between 2011 and 2013. It further explores the transparency of opposition organisations' relationships with TTCs and assesses the timing of their activities vis-à-vis key events in the policy process.

\section{METHODS}

Data collection and recording

In 2012, the Department of Health held a 4-month consultation (April to August) on standardised packaging for tobacco products. This attracted the largest ever response to a public consultation in the UK, and featured both strong opposition to and significant support for the measure (see online supplementary file 1$).{ }^{3}$ The study mapped opposition to standardised packaging during the 3-year period (1 January 2011-31 December 2013) straddling the consultation. ${ }^{50}{ }^{51}$ Data collection began in January 2013 and was prospective and retrospective. Using snowball sampling, data were predominantly collected from online sources, accessed via search engines and organisational website search functions. To facilitate this approach, web monitoring was employed, using both 'ASH Daily News' and daily search engine alerts for key words: packaging, plain, tobacco, cigarette, UK. Data were also gathered from freedom of information (FOI) requests made to the Department of Health, Intellectual Property Office and the Treasury. These requests asked for 'meetings, meeting notes, agendas, records of telephone conversations, or email or written correspondence with or from tobacco companies, lobby groups (eg, retail, business, trademarks) and/or think tanks where standardised or plain packaging of tobacco products was mentioned/discussed' specifying dates relevant to the study timeframe. Semistructured interviews (between 45 and $60 \mathrm{~min}$ ) were conducted with seven public health advocates to obtain background information and source further data. The study was also informed by leaked documents from Philip Morris International (PMI) ${ }^{52}{ }^{53}$ Written consent was provided by all interviewees.

Four hundred and twenty-two data items (including letters, videos, web articles and news items, press releases, adverts, reports) were identified. Data were imported into NVivo V.10 and recorded in a classification spreadsheet. The sample excluded blog posts, social media entries, correspondence sent in response to requests or enquiries from government departments, and consultation submissions (including associated cover letters), the latter having been analysed at length in other studies. ${ }^{54-56}$

\section{Data coding}

Data were coded for actor characteristics and political activity themes (table 1). In terms of inclusion criteria, 'actors' were defined as companies, organisations and groups whom the data showed undertook political activity to oppose, or to facilitate opposition to, standardised packaging. They were classified according to their role (identified from data), sector (identified from data and actors' websites) and relationship with major tobacco companies. Relationship was identified using a four step process: (1) data; (2) actors' websites, transparency registers and databases; (3) general web searches combining organisation names with TTC names; and (4) email enquiries. ${ }^{54}$ Political activities were coded deductively using themes based on Savell $e t a l^{57}$ The transparency of TTC involvement in activities was also coded from the data (table 1). All data were coded by JLH and discussed and agreed iteratively with GJF. Triangulation, prolonged engagement with the context, persistent observation of the data and peer debriefing were employed to ensure the validity of findings. ${ }^{59}$ 
Table 1 Classification system for participants and their activity in the conflict

\section{Classification of actors}

Role-determined from data

Active participants

Facilitative participants

Sector-determined from data and

Academia

Business

State

Relationship with tobacco companies-determined from data, actors' websites, transparency registers, general internet searches and email enquiries ${ }^{54}$

Financial

Core funding from one or more TTC

Campaign funding from one or more TTC

Membership funding or donation from one or more TTC

Client relationships with one or more TTC

Non-financial

Employee membership (where TTC employees were members of organisations)

Third party connections (where an indirect link exists between the actor and a TTC via a third party)

None

Unknown

Manufacturers

Classification of political activity

Type of political activity

Research production

Public communication

No relationship between the actor and any of the four major tobacco companies

Insufficient information to determine whether a relationship existed

Tobacco product and packaging manufacturing companies were exempt from classification for relationship

The commissioning and production of policy-relevant research

Public communication of arguments to the general public and to sectoral audiences

(eg, retailers, smokers) via the mainstream and sectoral media, including press, online,

films, events

Mass recruitment

Mass recruitment of the general public and of particular sectors to encourage responses to the 2012 consultation and communication with MPs and Ministers

Direct lobbying

Direct lobbying of politicians and civil servants via hospitality, meetings, events and publications and correspondence

Transparency of involvement of TTCs in political activity

Explicit

Implicit

Clear declaration of TTCs funding or involvement in activity-related documents

Activity-related documents did not include a declaration of TTC funding, but one could be found on the publishing website

Undeclared

Not applicable

Neither documents nor publishing website included a declaration of TTC funding

No evidence of TTC involvement in political activity

MPs, Members of Parliament; TTC, transnational tobacco company.

\section{Analysis}

First, we examined the data for number of organisations involved, their role in the conflict, their sector and their relationship with TTCs. Second, the volume, type, nature, timing and transparency of the different political activities undertaken by each actor were systematically quantified. This information was used to understand the pattern of activity by sector and relationship with TTCs. Third, interpretive qualitative analysis was used to obtain a deeper understanding of the purpose of the different types of activities identified.

\section{RESULTS}

Organisations opposing standardised packaging and their relationships with TTCs

One hundred and twenty-one organisations were identified as opposing standardised packaging within the study period (table 2). Of these, 78/121 (64.5\%) actively 
Table 2 Number, sector, role and relationships with TTCs of organisations $(n=121)$ opposing standardised packaging of tobacco products UK $2011-2013$

\begin{tabular}{|c|c|c|c|c|c|c|c|c|c|c|c|}
\hline \multirow[b]{2}{*}{ Category } & \multirow[b]{2}{*}{ Sector } & \multirow[b]{2}{*}{$\begin{array}{l}\text { Total number } \\
\text { of }(\%) \\
\text { organisations } \\
\text { per category, } \\
n=121\end{array}$} & \multicolumn{2}{|l|}{ Roles } & \multicolumn{3}{|c|}{ Relationships with TTCs, $n=109^{*}$} & \multicolumn{4}{|c|}{ Political activity, $n=404$} \\
\hline & & & $\begin{array}{l}\text { Number of } \\
\text { active } \\
\text { organisations }\end{array}$ & $\begin{array}{l}\text { Number of } \\
\text { facilitative } \\
\text { organisations }\end{array}$ & $\begin{array}{l}\text { Number of (\%) } \\
\text { financial } \\
\text { relationships } \\
\text { with tobacco } \\
\text { companies }^{58}\end{array}$ & $\begin{array}{l}\text { Number of (\%) } \\
\text { non-financial } \\
\text { relationships } \\
\text { with tobacco } \\
\text { companies }\end{array}$ & $\begin{array}{l}\text { Number of } \\
(\%) \text { no } \\
\text { relationship } \\
\text { with tobacco } \\
\text { companies } \\
\text { identified }\end{array}$ & Research & $\begin{array}{l}\text { Public } \\
\text { communication }\end{array}$ & $\begin{array}{l}\text { Mass } \\
\text { recruitment }\end{array}$ & $\begin{array}{l}\text { Direct } \\
\text { lobbying }\end{array}$ \\
\hline \multirow[t]{2}{*}{$\begin{array}{l}\text { Business } \\
\text { (tobacco) }\end{array}$} & $\begin{array}{l}\text { Tobacco } \\
\text { manufacturers }\end{array}$ & $12(10)$ & 4 & 0 & NA & NA & NA & $1 / \mathrm{C}$ & $22 / C$ & $1 / \mathrm{C}$ & $90 / \mathrm{C}$ \\
\hline & $\begin{array}{l}\text { Packaging and } \\
\text { design } \\
\text { companies }\end{array}$ & & 8 & 0 & NA & NA & NA & - & - & 4 & 7 \\
\hline \multirow[t]{5}{*}{$\begin{array}{l}\text { Business } \\
\text { (other) }\end{array}$} & $\begin{array}{l}\text { Investment } \\
\text { banks }\end{array}$ & $35(29)$ & 1 & 0 & $0(0)$ & $1(100)$ & 0 & 1 & - & - & - \\
\hline & $\begin{array}{l}\text { Media } \\
\text { companies }\end{array}$ & & 2 & 0 & $1(50)$ & $1(50)$ & 0 & - & 3 & 1 & 2 \\
\hline & Law firms $\dagger$ & & 1 & 5 & $5(83)$ & $1(17)$ & 0 & 4 & 2 & - & 5 \\
\hline & $\begin{array}{l}\text { Public relations } \\
\text { companies } \dagger\end{array}$ & & 1 & 6 & $7(100)$ & 0 & 0 & - & 2/C & C & 3 \\
\hline & $\begin{array}{l}\text { Research } \\
\text { consultancies } \dagger\end{array}$ & & 1 & 18 & $17(89)$ & $2(11)$ & 0 & 31 & 4 & - & - \\
\hline \multirow{6}{*}{$\begin{array}{l}\text { Business } \\
\text { associations }\end{array}$} & Manufacturing & 35 (29) & 2 & 0 & $2(100)$ & 0 & 0 & - & 5 & - & 3 \\
\hline & Packaging & & 1 & 0 & 0 & 0 & $1(100)$ & - & - & 1 & - \\
\hline & Wholesale & & 2 & 0 & $2(100)$ & 0 & 0 & - & 7 & 1 & 2 \\
\hline & Retail & & 10 & 0 & $8(80)$ & 0 & $2(20)$ & $-/ C$ & 45 & 4 & 7 \\
\hline & General & & 9 & 0 & $9(100)$ & 0 & 0 & - & 1 & - & 4 \\
\hline & $\begin{array}{l}\text { Intellectual } \\
\text { property }\end{array}$ & & 11 & 0 & $8(73)$ & $1(18)$ & $2(9)$ & $-/ C$ & 9 & - & 7 \\
\hline \multirow[t]{5}{*}{ Civil society } & Think tanks & $24(20)$ & 13 & 0 & $6(46)$ & $7(54)$ & 0 & 7 & 32 & $-1 S$ & 1 \\
\hline & $\begin{array}{l}\text { General rights } \\
\text { groups }\end{array}$ & & 5 & 0 & $2(40)$ & $2(40)$ & $1(20)$ & - & 22 & - & 1 \\
\hline & $\begin{array}{l}\text { Smokers' rights } \\
\text { groups }\end{array}$ & & 2 & 0 & $2(100)$ & 0 & 0 & - & 38 & 1 & 5 \\
\hline & $\begin{array}{l}\text { Unions } \\
\text { representing } \\
\text { tobacco } \\
\text { employees }\end{array}$ & & 2 & 0 & 0 & $2(100)$ & 0 & - & - & 1 & - \\
\hline & $\begin{array}{l}\text { Retired police } \\
\text { groups }\end{array}$ & & 2 & 0 & 0 & $1(50)$ & $1(50)$ & $-/ \mathrm{C}$ & 1 & - & - \\
\hline Academia & Universities† & $14(11.6)$ & 0 & 14 & $13(93)$ & $1(7)$ & 0 & 13 & - & - & - \\
\hline State & $\begin{array}{l}\text { Ad hoc } \\
\text { parliamentary } \\
\text { alliances }\end{array}$ & $1(<1)$ & 1 & 0 & 0 & $1(100)$ & 0 & - & - & - & 3 \\
\hline Total & & 121 & 78 & 43 & $82(75.2)$ & 20 (18.4) & $7(6.4)$ & 57 & 193 & 14 & 140 \\
\hline
\end{tabular}

Political activity: sectors which did not undertake specific political activities.

*Excludes tobacco and packaging companies.

tOrganisations commissioned to provide research, legal and public relations services to tobacco companies and other active organisations in the conflict.

C, commissioned or collaborated in activity; NA, not available; S, supported mass recruitment activities but did not initiate them; TTC, transnational tobacco company. 
opposed the policy (active participants). In total, 43/121 $(35.5 \%)$ were facilitative participants who provided legal, research and public relations services to active organisations, without directly opposing the policy on their own account.

Only 12/121 (10\%) were businesses from the tobacco or tobacco packaging manufacturing sectors (table 2). The remaining 109 organisations comprised: 35/121 (29\%) non-manufacturing businesses; 35/121 (29\%) business associations; $24 / 121(20 \%)$ civil society organisations; 14/121 (11.6\%) universities and 1/121 (<1\%), an ad hoc parliamentary alliance (table 2 and figure 1 ).

Of these 109 organisations, 82/109 (75.2\%) had financial relationships ${ }^{58}$ and 20/109 (18.4\%) non-financial relationships with at least one TTC (table 2 and figure 1). The remaining 7/109 (6.4\%) organisations comprised one which was found to have no connection with any tobacco company, and six which could not be classified due to insufficient information.

Ten of the organisations with financial relationships with TTCs were found to be in receipt of core and/or antistandardised packaging campaign funding, 30 had tobacco company members or had received tobacco company donations, and 42 had tobacco company clients. One hundred per cent of smokers' rights groups, public relations and lobbying firms, manufacturing, wholesale and general business associations were found to have financial relationships with TTCs (table 2). Ninety per cent or more of universities, and $80 \%$ or more of law firms, research consultancies and retail associations identified in the research were also financially linked to TTCs. Of the 20 organisations with non-financial relationships, 17 were connected with tobacco companies via a third party. For example, organisations were linked to TTCs via bridging actors engaged in either neoliberal or business networks and tobacco company-funded activity. Others were subcontracted by organisations commissioned by tobacco companies or had collaborated with tobacco company consultants. ${ }^{54}$ Three included tobacco company employees among their members.

\section{Opposition organisations' political activity}

Political activities were extensive $(n=404$, identified from the 422 documents) and entailed four main types of action: production of policy-relevant research $(57,14 \%)$; public communication (193, 48\%); mass recruitment $(14,3 \%)$ and direct lobbying $(140,35 \%)$.

Different sectors focused on different types of activity (table 2 and figure 2). TTCs (114/404, 28\%) were particularly active in direct lobbying of government. Civil society organisations $(109 / 404,27 \%)$ and business

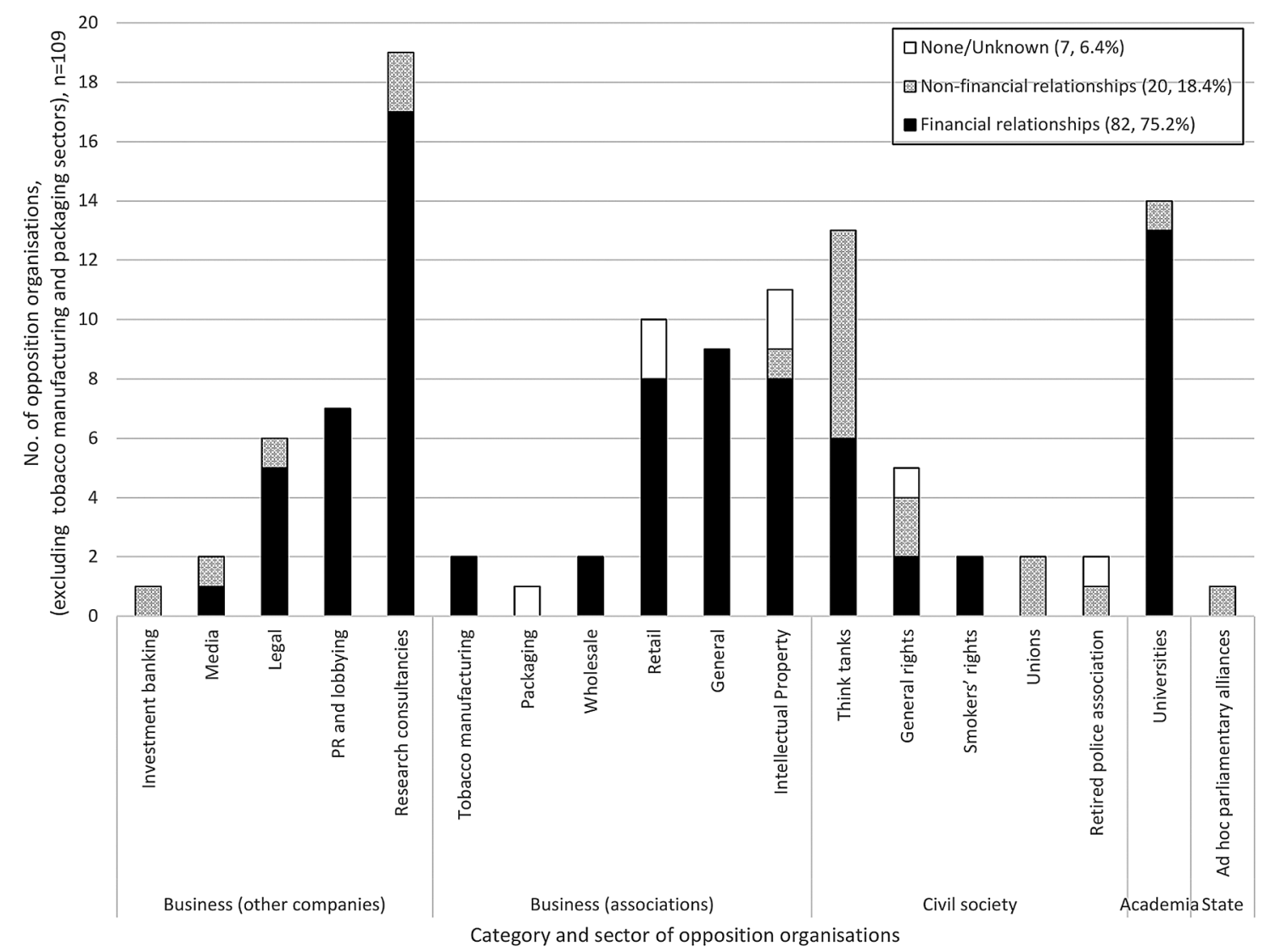

Figure 1 Number, sector and relationship with TTCs of organisations opposing, or facilitating opposition to, standardised packaging in the UK 2011-2013 (excludes tobacco manufacturing, packaging and design companies), $n=109$. PR, public relations; TTC, transnational tobacco company. 
associations $(96 / 404,24 \%)$ prioritised public communications. Other companies $(58 / 404,14 \%)$, predominantly comprising law and public relations firms, and academic actors $(13 / 404,3 \%)$ mainly produced research. Packaging and design firms undertook a small number of mass recruitment and direct lobbying activities $(11 / 404,3 \%)$. State actors only undertook direct lobbying $(3 / 404,1 \%)$.

The distribution of opposition activities also varied with organisations' relationships with TTCs (figure 3).

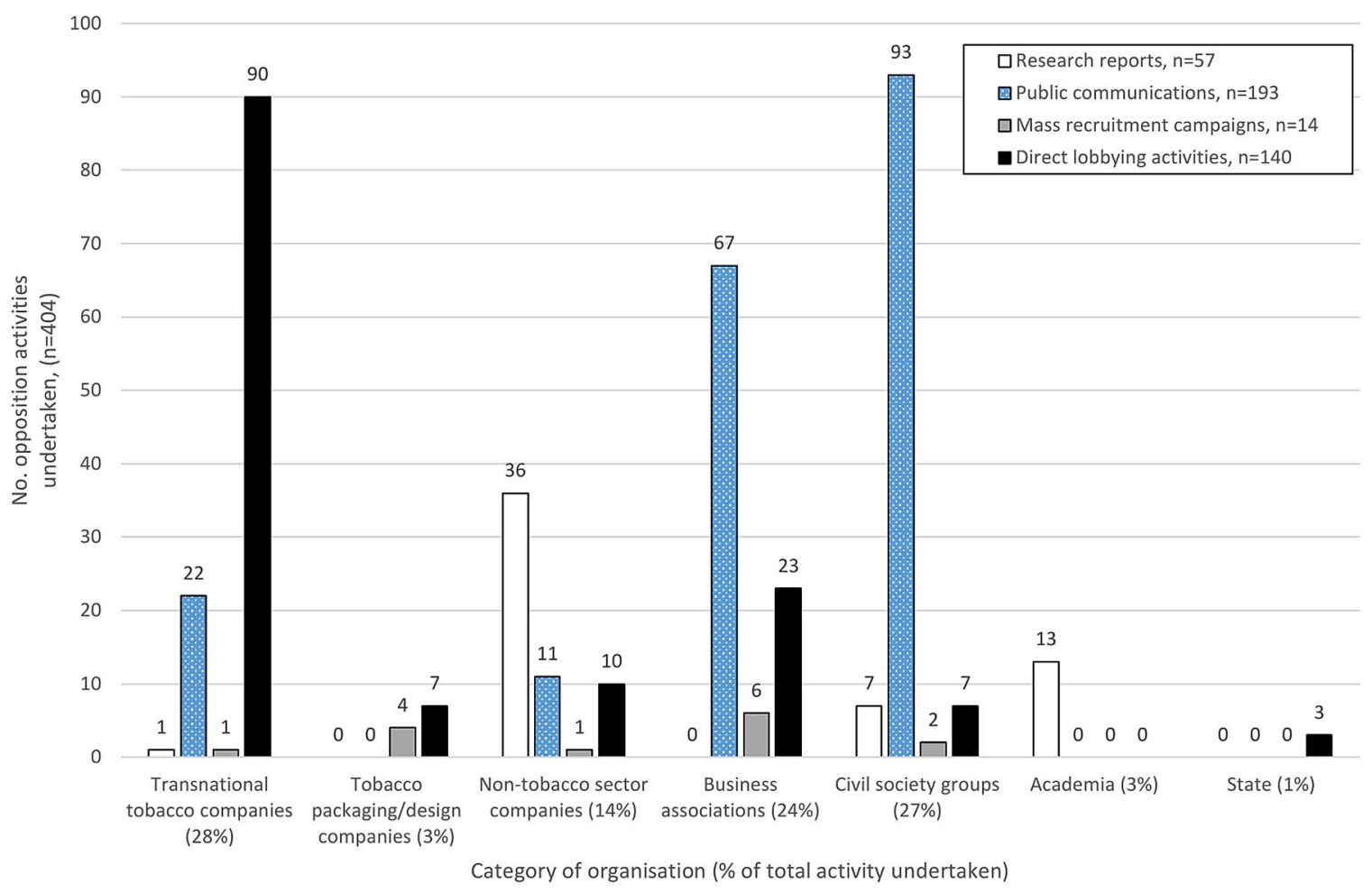

Figure 2 Volume and distribution by sector of activities undertaken or cited to oppose standardised packaging 2011-13, n=404.

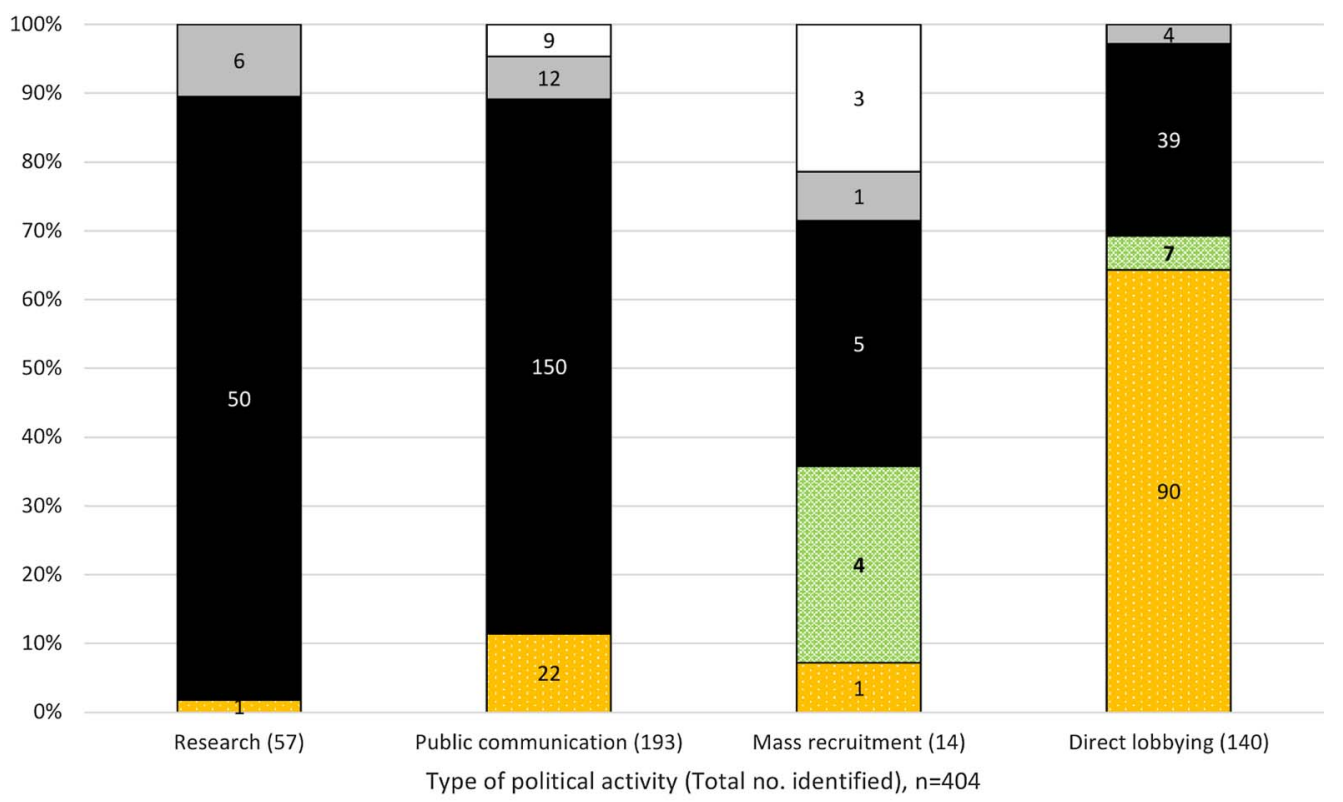

$\square$ None/Unknown (12, 3\%)

$\square$ Organisations with non-financial relationships with $\operatorname{TTCs}(23,6 \%)$

- Organisations with financial relationships with TTCs $(244,60 \%)$

Packaging Companies (11,3\%)

$\square$ Transnational tobacco companies $(114,28 \%)$

Figure 3 Distribution of types of political activity by relationship of organisations with TTCs, $n=404$. TTC, transnational tobacco company. 
Organisations financially related to TTCs undertook the majority $(244 / 404,60 \%)$ of all opposition activities, including nearly 9 out of 10 research reports and threequarters of public communications. Organisations with non-financial relationships undertook all four activity types $(23 / 404,6 \%$; figure 3$)$. The data reveal how activities combined to form both 'insider' and 'outsider' political strategies. For example, research produced by third parties was frequently cited in lobbying activities and business and civil society organisations were found to collaborate on public communications and mass recruitment campaigns (table 3).

Table 3 Examples of 'insider' and 'outsider' activities undertaken by TTCs and opposition organisations

\begin{tabular}{ll}
\hline Political strategy type & Political activities* \\
\hline Insider strategy: research & PMI commission an opinion from Lord \\
production and direct & Hoffman, which they and public relations \\
lobbying & firm, Crosby Textor Fullbrook (retained by \\
& PMI), promote to ministers and officials in \\
& the Intellectual Property Office.
\end{tabular}

\section{Extracts}

"A prohibition on the use of a mark is in my view a complete deprivation of the property in that mark, notwithstanding that the proprietor might be able to distinguish his goods by the use of some other mark."

Lord Hoffman, Philip Morris International: Opinion, 24.05.12 $12^{61}$

"I will send you the Lord Hoffman opinion in the near future as I'm sure it would be of interest to you."

Philip Morris Ltd email to the Intellectual Property

Office, Fw: Meeting follow up-21 June 2012-

Email $125.06 .12^{62}$

Outsider strategy: public communication and mass recruitment
BAT, ITG and JTI core-fund active organisations (Forest, Hands Off Our Packs (HOOPs)) who mobilise support from other organisations to help promote their antistandardised packaging messaging, eventually generating nearly 270000 antistandardised packaging signatures. ${ }^{3} 64$
"My dear Lord, please find enclosed as promised a telling opinion from Lord Hoffman...Hoffman is the most telling and concerning from an IP viewpoint."

Lynton Crosby, Crosby-Textor-Fullbrook, email to Lord Marland, Minister for Intellectual Property,

$01.11 .12^{63}$

"Angela Harbutt [head of HOOPs]... believed the proposal was the most ill-conceived, idiotic and illiberal idea that had come out of any UK government during the past five or 10 years. She said that it was a fight that had to be won, and she asked those present to sign up to the campaign and to spread the word."

Forest on the HOOPs campaign launch, $27.02 .12^{65}$

"When the government came to power, I don't remember them saying it was going to be a priority for them to increase regulation and persecute minority lifestyle choices. But that's what this consultation is about....So please sign up to the HOOPs campaign and do everything you can to stop this ridiculous new growth of the nanny state."

Mark Littlewood, Director, Institute of Economic Affairs, in HOOPs' campaign film, Nannytown, $07.03 .12^{66}$

"It's about time we called a halt to the advance of the 'nanny state' and reasserted the historic British values of tolerance and freedom."

Andrew Turner, CEO, API Group (packaging), interviewed by HOOPs, 01.05.12

${ }^{*}$ For more information on these cases see http://www.tobaccotactics.org.

PMI, Philip Morris International; TTC, transnational tobacco company. 
Production of research

Nearly 9 of every 10 research reports $(50 / 57,88 \%)$ were authored by organisations with a financial relationship with TTCs (figure 3). They presented similar arguments to tobacco company consultation submissions, where they were widely quoted, ${ }^{55}$ and to PMI's antistandardised packaging strategy (leaked to the public health nongovernmental organisation, Action on Smoking and Health). ${ }^{52} 53$ These were: negative economic, illicit trade, intellectual property and trade and price consequences of standardised packaging; criticism of the policy process; and lack of evidence of effect. The data showed that commissioned research reports were used by TTCs and financially linked actors to support opposition arguments in public communication and direct lobbying activities.

\section{Public communications}

Over three-quarters $(150 / 193,78 \%)$ of public communications were undertaken by 35 business associations, civil society groups and a public relations firm with financial relationships with TTCs (figure 3). Public communications replicated TTCs' main arguments against standardised packaging, and disseminated them to general and sectoral audiences. General audience communications included press releases, films raising the spectres of illicit tobacco and the "nanny state',66 68-72 advertisements subsequently judged to be in breach of the Advertising Standards Authority's code ${ }^{73-77}$ and articles in the mainstream media. Sectoral communications included articles, news stories and events directed at specific groups, such as retailers and intellectual property professionals. ${ }^{78-81}$ The combination of general and sectoral communications found in the data suggests that TTCs, and other opponents of standardised packaging, were cognisant of the power of different media to raise the significance of this policy among different constituencies. Such communications may have contributed to the intensity of the 2012 consultation response (see mass recruitment) and indirectly to the period of seeming political inactivity which followed.

\section{Mass recruitment}

Five mass recruitment campaigns were undertaken by organisations financially linked to TTCs and one by Imperial Tobacco Group themselves (figure 3 and table 4). Campaigns aimed to encourage the general public and targeted constituencies to submit postcard, standard letter or petition-style responses to the 2012 consultation and to lobby Members of Parliament (MPs) and Ministers. ${ }^{3} 5253$ Campaign materials were promoted online, in the workplace and in the street and reflected TTC arguments. ${ }^{83} 8586$ The largest campaign, Hands Off Our Packs, extended its reach by commissioning street marketing in $30 \mathrm{UK}$ cities ${ }^{87}$ and collaborating with sympathetic organisations (table 3). ${ }^{66} 88-92$ The five mass recruitment campaigns directly funded by TTCs generated $420394 / 427812$ (98\%) opposition campaign submissions. ${ }^{3}$ Mass recruitment campaigns aimed to translate opposition-oriented general and sectoral opinion (underpinned by public communications) into mass political action.

\section{Direct lobbying of policymakers}

Over a quarter $(39 / 140,28 \%)$ of direct lobbying was undertaken by organisations financially linked to TTCs and nearly two-thirds $(90 / 140,64 \%)$ by TTCs themselves (figure 3). Direct lobbying included: 32 hospitality gifts valued at $£ 32583$ from JTI; ${ }^{93} 17$ meetings with government officials at the Treasury, Department of Health and Intellectual Property Office; ${ }^{62}$ 94-101 9 events, including in Parliament on the illicit trade $\mathrm{e}^{102-106}$ and party conferences; ${ }^{107} 108$ publications in parliamentary magazines; ${ }^{82} 84109$ and 82 correspondence items sent mainly to the Department of Health, the Treasury and the Intellectual Property Office. ${ }^{110-120}$ Correspondence included letters from an ad hoc group of 50-74 MPs, 8 of whom had previously accepted gifts from JTI. ${ }^{93}$ 121-123 Direct lobbying activities drew on the range of arguments promoted by TTCs, and flagged or enclosed industrycommissioned research reports (table 3).

\section{Transparency of tobacco industry involvement in opposition activities}

Active organisations with financial relationships with TTCs $(n=43)$ were transparent in only half of correspondence $(15 / 31,48 \%), 1$ of 4 research reports ${ }^{124}$ and $<1$ in 5 public communications $(27 / 150,18 \%)$. For example, in public communications former police officers did not declare membership of the Common Sense Alliance (a FOREST offshoot). ${ }^{125-129}$

In contrast, TTCs $(n=4)$ and facilitative actors with financial relationships with them $(n=39)$ were transparent in reporting their interests. All but one research reports $(41 / 42,98 \%)$ declared their source of funding, although references to authorial independence, experience and qualifications were used to offset potential negative effects of corporate funding on credibility. ${ }^{55}$ Yet, when promoted by active participants in the conflict, TTC funding of research was only acknowledged in 6/20 $(30 \%)$ citations in press releases ${ }^{130-135}$ and in $4 / 35$ $(11 \%)$ citations in direct lobbying correspondence. ${ }^{136-139}$

\section{Timing of political activity}

Peaks in opposition political activity coincided with the Australian public consultation (April to June 2011, when JTI made 17 gifts to MPs), the UK public consultation (April to August 2012), the Department of Health announcement that they would 'wait and see' what evidence emerged from Australia (July 2013) ${ }^{3}{ }^{140}$ and the decision to establish the independent Chantler Review of evidence on standardised packaging (November 2013) (figure 4 and see online supplementary file 1). ${ }^{26}{ }^{141}$ Research publications peaked early in June 2012, midway through the consultation. Public communications dominated in the period leading into the 
Table 4 Mass recruitment campaigns to oppose standardised tobacco packaging, $n=14$

(tobacco)

Business

(other)

Business

associations

Total

\section{Actor information}

Mass recruitment campaign details

Category Sector

Business Tobacco

manufacturers

Packaging and

design companies

Name

Imperial Tobacco

Benkert

Chesapeake

Parkside Flexibles

Weidenhammer

Media companies Asian Media and

Marketing Group

Unnamed packaging

employees group

Scottish Wholesale

Association

Association of

Independent

Tobacconists

National Federation of

Retail Newsagents

Tobacco Retailers

Alliance

Unnamed retailers'

group

Civil Society Smokers' rights

Hands Off Our Packs

and Forest

Unions

Unite and GMB
Tobacco
company

Direct

commercial

Direct

commercial

Direct

commercial

Direct

commercial

Direct

commercial

Financial

funding?

Recruitment targets

Say NO to plain packs ITG

(Unnamed)

NA

Say 'No' to standardised

NA

packaging

(Unnamed)

NA

(Unnamed)

NA

(Unnamed)

Unknown

(Unnamed)

Financial

Plain Nonsense

Unknown

(Unnamed)

(Unnamed)

Financial

Financial

No to 'plain' packs

Unknown

Financial

(Unnamed)

Non-financial

Hands Off Our Packs

Plain packaging of tobacco products: Caution UK jobs at risk

General public

Packaging employees

Packaging employees

$\begin{array}{lll}\text { PMI, ITG } & \\ & & \text { Retailers }\end{array}$

NA

BAT, ITG ${ }^{83} 84 \quad$ Unknown 2865

NA

Specialist

tobacconists and

customers

NA Retailers

BAT, ITG, JTI Retailers 26530

NA

Small retailers

BAT, ITG, JTI

General Public

NA

Tobacco, print and packaging employees

Number of

submissions

120247

131

79

Packaging employees 196

Packaging employees 869

Packaging employees 175

3199

6

561

269854 2202

Source: Department for Health. ${ }^{3}$ The figure 427812 is at variance with that quoted in the

policemen. These are included elsewhere in the analysis of political activity in the paper.

MPs, Members of Parliament; NA, not available. 
25

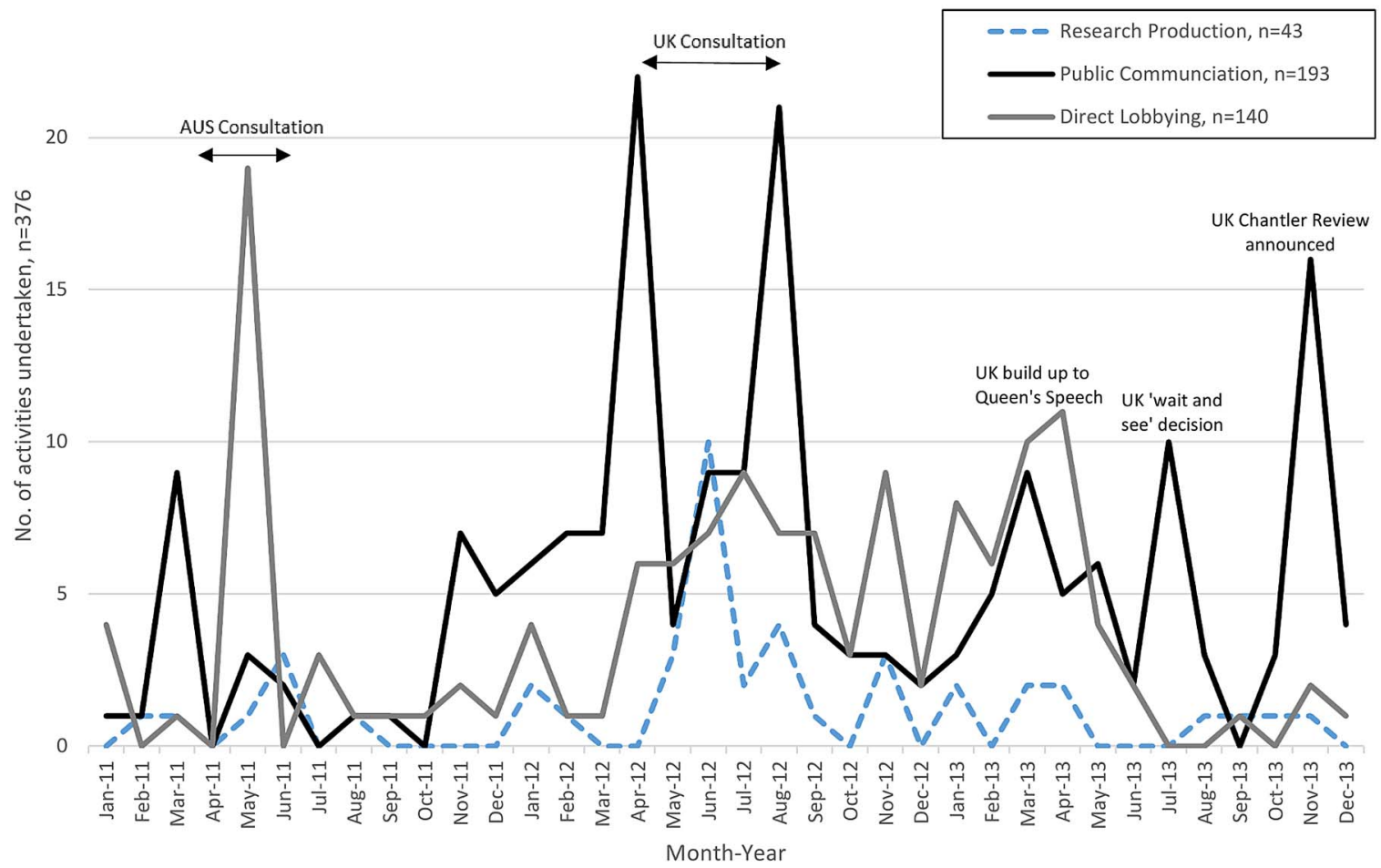

Figure 4 Timing of opposition political activity 2011-2013, n=376 (excludes 14 mass recruitment campaigns which occurred over a series of months and 14 research reports which were published between 2008 and 2010 but were subsequently used by conflict participants between 2011 and 2013).

consultation and again when the Chantler Review was announced. Direct lobbying occurred throughout but was particularly prevalent in the period after the consultation, when the government emphasised that it had an 'open mind'. ${ }^{142-144}$

\section{DISCUSSION}

Nearly 9 of every 10 political activities undertaken to oppose standardised packaging were financially linked to the tobacco industry. Eighty-two diverse third party organisations with financial relationships with $\mathrm{TTCs}^{58}$ undertook $60 \%$ of all opposition activity, including the vast majority of research production $(88 \%)$ and public communications $(78 \%)$. Active organisations among them were rarely transparent about their relationship with TTCs. TTCs undertook $28 \%$ of activities themselves, including $64 \%$ of all direct lobbying. While previous research has identified TTCs' use of third parties, ${ }^{54} 145$ this is the first paper to quantify the extent of TTC-supported political activity. It shows that the majority of activities undertaken to oppose standardised tobacco packaging in the UK were linked to the tobacco industry. The significance of this for public health policy debates should not be underestimated.

TTCs' long-term and campaign-specific support for third parties expanded the policy conflict ${ }^{146}{ }^{147}$ in two key respects. First, it increased the capacity of participants in the conflict to undertake opposition activities.
Second, it helped mobilise the support of a diverse range of constituencies including the wholesale and retail sectors-which the official impact assessment found were likely to be only marginally affected by standardised packaging ${ }^{46}$ - and general business and civil society groups-who had no direct financial interest in the outcome of the conflict. The high proportion of opposition organisations that received financial subsidies from TTCs highlights the power of industry money to induce and augment political action. ${ }^{148-151}$ Membership subscriptions and other long-term financial subsidies to organisations create a form of latent political capital that can be drawn on in the context of specific health policy conflicts. Industry funds research to underpin and arguably enhance the legitimacy of public communications and lobbying. ${ }^{106}{ }^{152-154}$ Direct campaign subsidies lower the costs of political activity, and increase the range of politically important constituencies that can be effectively targeted and mobilised by industry arguments. ${ }^{155} 156$

These findings illustrate the importance of third parties to TTCs' insider and outsider political strategies ${ }^{41} 42$ as they adapt to both Article 5.3 of the FCTC ${ }^{35} 36$ and to Better Regulation. ${ }^{37}$ With regard to insider political strategies, TTC financial and in-kind support for third party policy-facing activities (direct lobbying, research production) is instrumental in off-setting government commitments under Article 5.3 to reduce tobacco industry access to policymakers. This is consistent with research which uncovered extensive third party industry lobbying 
against the European Union Tobacco Products Directive. ${ }^{145} 157$ Subsidising research production also optimises TTCs' opportunities to capitalise on the importance of evidence in shaping mandatory impact assessments. ${ }^{54} 55$

Subsidising public-facing third party activities (mass recruitment, public communication, research promotion) was central to the industry's outsider strategy. These activities aimed to expand the conflict by mobilising specific constituencies and the general public against standardised packaging at key points within the policy process. For example, TTC funding of mass recruitment campaigns during the 2012 consultation produced 98\% of submissions objecting to the policy. ${ }^{3}$ The absence of an immediately observable link between these active third party activities and the industry is likely to have been instrumental in their effectiveness, ${ }^{54}$ helping to create an impression of strong opposition to the policy from a wider range of constituencies. This is consistent with efforts by active opponents of standardised packaging to present the consultation as a referendum on the policy, ${ }^{158}$ despite the wealth of supportive evidence, ${ }^{18} 26$ the support of the majority of MPs ${ }^{50159}$ and opinion polls showing that only $11 \%$ of the general public opposed the measure. ${ }^{160} 161$ This practice represents a highly public way of formally registering dissent to policy proposals ${ }^{38} 145157162$ and presents further evidence of industry adaptation to the opportunities for influence inherent within Better Regulation processes.

The unique contribution of the study lies in the innovative combination of publicly available sources and investigative research techniques, which facilitates analysis of both the scale of political action in contemporary health policy conflicts and the degree of support provided by the tobacco industry. By making explicit the links between ostensibly independent organisations opposing tobacco policy and TTCs, the research aims to reduce the utility of their third party strategy for opposing public health policies. Further innovation comes from the systematic classification of the sector and relationships of actors engaged in political activity, which enables the examination of relationships between ostensibly distinct groups opposing public health policy. This is a novel system which could be applied to increase understanding of how corporations in other sectors responsible for producing commodities harmful to health (eg, alcohol, sugar-sweetened beverages) oppose population level policy instruments. By outlining the relationships between TTCs and other organisations in the conflict around standardised packaging and mapping these relationships to political actions, the study builds on the political science literature which primarily focuses on the role of civil society groups in expanding policy conflicts and understates the role of financial subsidies to conflict participants. ${ }^{38} \quad 57 \quad$ 162-167 The findings complement research examining tobacco industry arguments, strategies and tactics used in Australia to oppose standardised packaging. ${ }^{168}$
The ongoing nature of the policy process during the study period limited access to key sources of data. Officials from the Department of Health declined requests for interview. Some FOI requests were declined under section 35 of the Freedom of Information Act (FOIA), which exempts the release of information relating to 'the formulation or development of government policy' 169170 and the Regulatory Policy Committee (a key organisation responsible for approving impact assessments ${ }^{40}$ ) is not covered by FOIA. ${ }^{171}$ The practical requirements of data volume led to the exclusion of social media data from the study. It is thus possible that the volume of tobacco industry-supported activity and the extent and nature of relationships between TTCs and third parties were greater than is revealed by the study. Supplementary research using social network and social media analysis would provide deeper insights into how protobacco policy networks are formed and operate.

Our findings have major policy implications of relevance to parties to the FCTC and to countries where Better Regulation processes are integral to the policy process. First, and most importantly, the high incidence of financial relationships between tobacco manufacturers and third party opponents highlights the need for all policymakers, and the media, ${ }^{172}$ to treat organisations in tobacco policy conflicts with scepticism and to routinely require declarations of financial relationships in all interactions. To strengthen implementation of Article 5.3 of the FCTC, governance reforms should be introduced to require: (1) regular reports from TTCs on their affiliations, political activities and associated expenditure; and (2) the establishment of a transparent system of disclosure, through which all non-tobacco industry organisations lobbying any part of government on tobacco control must always disclose core funding, donations and membership fees from TTCs.

In addition, evidence of government-wide lobbying underlines the importance of health officials raising awareness and sharing information with other government departments regarding industry interference in public policy in accordance with the guidelines for implementation of Article 5.3. ${ }^{35}$ The scale and complexity of relationships between TTCs and other organisations engaged in tobacco policy conflicts reaffirms the importance of industry monitoring. ${ }^{173}{ }^{174}$ Finally, the timing and scale of industry-funded research, which, ultimately, feeds into stakeholder consultations and impact assessments, ${ }^{44}$ highlights the importance of continued funding of policy-relevant research by public and third sector organisations.

Acknowledgements The authors warmly acknowledge the contribution made by Dr Karen Evans-Reeves and Ms Silvy Peeters of the Tobacco Control Research Group at the University of Bath for their invaluable contribution to developing the actor classification structure described in this paper.

Contributors The study was conceived by GJF and ABG; data were collected, coded and analysed by JLH who also wrote the first draft; GJF contributed to data coding and analysis; JLH, GJF and ABG all contributed to subsequent drafts. 
Funding The work was supported by Cancer Research UK (Grant no. C38058/A15664). GJF was funded by the National Cancer Institute at the National Institutes of Health (Grant no. R01CA160695). JLH and ABG are members of the UK Centre for Tobacco and Alcohol Studies.

Competing interests $A B G$ is a member (unpaid) of the Council of Action on Smoking and Health, and was a member of the WHO Expert Committee convened to develop recommendations on how to address tobacco industry interference with tobacco control policy.

Ethics approval Ethical approval for the project was obtained from the REACH Committee, Department for Health Ethics Committee at the University of Bath.

Provenance and peer review Not commissioned; externally peer reviewed.

Data sharing statement More information about the data can be accessed from http://tobaccotactics.org/index.php/Plain packaging in the UK: TCRG Research_on_Policy_Opposition_2011-2013.

Open Access This is an Open Access article distributed in accordance with the terms of the Creative Commons Attribution (CC BY 4.0) license, which permits others to distribute, remix, adapt and build upon this work, for commercial use, provided the original work is properly cited. See: http:// creativecommons.org/licenses/by/4.0/

\section{REFERENCES}

1. Department of Health. Consultation on the future of tobacco control. London, 2008. http://webarchive.nationalarchives.gov.uk 20130107105354/http://www.dh.gov.uk/prod_consum_dh/groups/ dh_digitalassets/documents/digitalasset/dh_085651.pdf (accessed Feb 2016)

2. HM Government. Healthy lives, healthy people: a tobacco control plan for England. London, 2011. https:/www.gov.uk/government/ uploads/system/uploads/attachment_data/file/213757/dh_124960. pdf (accessed Feb 2016).

3. Department of Health. Consultation on standardised packaging of tobacco products: summary report. London, July 2013. https://www. gov.uk/government/consultations/ standardised-packaging-of-tobacco-products (accessed Feb 2016)

4. Department of Health. Consultation on the introduction of regulations for standardised packaging of tobacco products: summary report. London: UK Government, 2015. https://www.gov. uk/government/uploads/system/uploads/attachment data/file/ 403489/Consultation_summary.pdf (accessed Feb 2016).

5. Department of Health. Government backs standardised packaging of tobacco. London, 2015 (updated 21 January 2015). https://www. gov.uk/government/news/

government-backs-standardised-packaging-of-tobacco (accessed Feb 2016).

6. UK Government. Public health: the standardised packaging of tobacco products regulations. UK: The Stationery Office Ltd., 2015. http://www.legislation.gov.uk/ukdsi/2015/9780111129876/pdfs/ ukdsi_9780111129876_en.pdf (accessed Feb 2016).

7. Harris F, MacKintosh AM, Anderson S, et al. Effects of the 2003 advertising/promotion ban in the United Kingdom on awareness of tobacco marketing: findings from the International Tobacco Control (ITC) Four Country Survey. Tob Control 2006;15(Suppl 3):iii26-33.

8. Kasza KA, Hyland AJ, Brown A, et al. The effectiveness of tobacco marketing regulations on reducing smokers' exposure to advertising and promotion: findings from the International Tobacco Control (ITC) Four Country Survey. Int $J$ Environ Res Public Health 2011;8:321-40.

9. Harper T. Marketing life after advertising bans. Tob Control 2001;10:196-8.

10. Carter OBJ, Phan T, Mills BW. Impact of a point-of-sale tobacco display ban on smokers' spontaneous purchases: comparisons from postpurchase interviews before and after the ban in Western Australia. Tob Control 2015;24:e81-6.

11. Li L, Borland R, Fong GT, et al. Impact of point-of-sale tobacco display bans: findings from the International Tobacco Control Four Country Survey. Health Educ Res 2013;28:898-910.

12. Rooke C, Cheeseman H, Dockrell M, et al. Tobacco point-of-sale displays in England: a snapshot survey of current practices. Tob Control 2010;19:279-84.

13. Paynter J, Edwards R, Schluter PJ, et al. Point of sale tobacco displays and smoking among 14-15 year olds in New Zealand: a cross-sectional study. Tob Control 2009;18:268-74.
14. Moodie C, Angus K, Ford A. The importance of cigarette packaging in a 'dark' market: the 'Silk Cut' experience. Tob Control 2014;23:274-8

15. West R. Preventing tobacco companies from advertising using their packaging could be an important component of comprehensive tobacco control: a commentary on Australia's plain packaging of cigarettes. Drug Alcohol Rev 2011;30:681-2.

16. Greenland SJ. Cigarette brand variant portfolio strategy and the use of colour in a darkening market. Tob Control 2015;24(e1): e65-71.

17. Hulit M. Marketing issues corporate affairs conference 940527 Manila. 1994 May 27. Philip Morris. https://www. industrydocumentslibrary.ucsf.edu/tobacco/docs/qsbd0116

18. Moodie C, Stead M, Bauld L, et al. Plain tobacco packaging: a systematic review. London: EPPI-Centre, 2012. http://eppi.ioe.ac.uk/ cms/Default.aspx?tabid=3327 (accessed Feb 2016).

19. Ford A, Moodie C, Hastings $G$. The role of packaging for consumer products: understanding the move towards 'plain' tobacco packaging. Addict Res Theory 2012;20:339-47.

20. Gallopel-Morvan K, Gabriel P, Le Gall-Ely M, et al. Plain packaging and public health: the case of tobacco. J Bus Res 2013;66:133-6.

21. Hoek J, Gendall P, Gifford H, et al. Tobacco branding, plain packaging, pictorial warnings, and symbolic consumption. Qual Health Res 2012;22:630-9.

22. Maynard OM, Munafò MR, Leonards U. Visual attention to health warnings on plain tobacco packaging in adolescent smokers and non-smokers. Addiction 2013;108:413-19.

23. Moodie C, Hastings G, Joossens L. Young adult smokers perceptions of illicit tobacco and the possible impact of plain packaging on purchase behaviour. Eur J Public Health 2012;22:251-3.

24. Wakefield M. Welcome to cardboard country: how plain packaging could change the subjective experience of smoking. Tob Control 2011;20:321-2.

25. Scheffels J, Lund I. The impact of cigarette branding and plain packaging on perceptions of product appeal and risk among young adults in Norway: a between-subjects experimental survey. BMJ Open 2013;3:e003732.

26. Chantler C. Standardised packaging of tobacco: report of the independent review undertaken by Sir Cyril Chantler. London: King's College London, 2014. http://www.kcl.ac.uk/health/ 10035-TSO-2901853-Chantler-Review-ACCESSIBLE.PDF (accessed Feb 2016).

27. Smith CN, Kraemer JD, Johnson AC, et al. Plain packaging of cigarettes: do we have sufficient evidence? Risk Manag Healthc Policy 2015;8:21-30.

28. Department of Health AG. Post-implementation review: Tobacco plain packaging. 2016 (updated 26 February 2016). https://ris. govspace.gov.au/files/2016/02/Tobacco-Plain-Packaging-PIR.pdf

29. Brennan E, Durkin S, Coomber K, et al. Are quitting-related cognitions and behaviours predicted by proximal responses to plain packaging with larger health warnings? Findings from a national cohort study with Australian adult smokers. Tob Control 2015;24 (Suppl 2):ii33-41.

30. Durkin S, Brennan E, Coomber K, et al. Short-term changes in quitting-related cognitions and behaviours after the implementation of plain packaging with larger health warnings: findings from a national cohort study with Australian adult smokers. Tob Control 2015;24(Suppl 2):ii26-32.

31. Wakefield M, Coomber K, Zacher M, et al. Australian adult smokers' responses to plain packaging with larger graphic health warnings 1 year after implementation: results from a national cross-sectional tracking survey. Tob Control 2015;24(Suppl 2): ii17-25.

32. White $\mathrm{V}$, Williams $\mathrm{T}$, Faulkner $\mathrm{A}$, et al. Do larger graphic health warnings on standardised cigarette packs increase adolescents' cognitive processing of consumer health information and beliefs about smoking-related harms? Tob Control 2015;24(Suppl 2): ii50-7.

33. White $\mathrm{V}$, Williams $\mathrm{T}$, Wakefield $\mathrm{M}$. Has the introduction of plain packaging with larger graphic health warnings changed adolescents' perceptions of cigarette packs and brands? Tob Control 2015;24(Suppl 2):ii42-9.

34. McNeill A. Plain packaging: Weighing up the evidence on standardised packaging for tobacco products. 2015. http:// onlinelibrary.wiley.com/journal/10.1111/(ISSN)1360-0443/ homepage/plain_packaging.htm (Archived by WebCite ${ }^{\circledR}$ at http:// www.webcitation.org/6jdPJ3KDe) (accessed Aug 2016).

35. World Health Organisation. Guidelines for implementation of Article 5.3 of the WHO Framework Convention on Tobacco Control. 
Geneva, 2009. http://www.who.int/fctc/guidelines/article_5_3.pdf (accessed Feb 2016)

36. World Health Organisation. Framework convention on tobacco control. Geneva: WHO Library, 2003. http://www.who.int/fctc/en/ (accessed Feb 2016)

37. Department for Business Innovation and Skills. Better regulation framework manual. London: UK Government, 2013. https://www. gov.uk/government/publications/better-regulation-framework-manual (accessed Feb 2016).

38. Smith KE, Fooks G, Gilmore AB, et al. Corporate coalitions and policy making in the European Union: how and why British American Tobacco promoted "Better Regulation". J Health Polit Policy Law 2015; 40:325-72.

39. Smith KE, Gilmore AB, Fooks G, et al. Tobacco industry attempts to undermine Article 5.3 and the "good governance" trap. Tob Control 2009;18:509-11.

40. Gibbons M, Parker D. Impact assessments and better regulation: the role of the UK's regulatory policy committee. Public Money Manag 2012;32:257-64.

41. Betzold C. Business insiders and environmental outsiders? Advocacy strategies in international climate change negotiations. Interest Groups Advocacy 2013;2:302-22.

42. Maloney WA, Jordan G, McLaughlin AM. Interest groups and public policy: the insider/outsider model revisited. $J$ Public Policy 1994;14:17-38.

43. Smith KE, Fooks G, Collin J, et al. Is the increasing policy use of Impact Assessment in Europe likely to undermine efforts to achieve healthy public policy? J Epidemiol Community Health 2010;64:478-87.

44. Department of Health. Impact assessment: standardised packaging of tobacco products. London: UK Government, 2014. https://www. gov.uk/government/uploads/system/uploads/attachment_data/file/ 323518/impact_assessment.pdf (accessed Feb 2016).

45. Department of Health. Impact assessment: standardised packaging for tobacco products. London: UK Government, 2012. http:// consultations.dh.gov.uk/tobacco/

standardised-packaging-of-tobacco-products/supporting documents $/ 17194 \% 20$ Impact $\% 20$ assessment $\% 20 \%$ 20Standardised\%20packaging\%20of\%20tobacco\%20products\% 20final.pdf (accessed Feb 2016).

46. Department of Health. Standardised packaging of tobacco products: impact assessment. London: UK Government, 2015 (updated 10 February 2015). https://www.gov.uk/government/ uploads/system/uploads/attachment data/file/403493/lmpact assessment.pdf (accessed Feb 2016).

47. Radaelli CM. Regulating rule-making via impact assessment. Governance 2010;23:89-108.

48. Radaelli C. Better regulation in Europe: between public management and regulatory reform. Public Adm 2009;87:639-54

49. University of California and Center for Knowledge Management. Legacy tobacco documents library. San Francisco, 2002-2015. https://industrydocuments.library.ucsf.edu/tobacco/ (accessed Feb 2016).

50. Barber S, Conway L. Standardised (plain) packaging of tobacco products. London: House of Commons Library, 2015 (updated 22 January 2015). http://www.parliament.uk/business/publications/ research/briefing-papers/SN06175/

standardised-packaging-of-tobacco-products (accessed Feb 2016)

51. Department of Health. Consultation on standardised packaging of tobacco products. London: Williams Lea, 2012 (updated June 2014). https://www.gov.uk/government/consultations/ standardised-packaging-of-tobacco-products (accessed Feb 2016).

52. Philip Morris International, UK Corporate Affairs Update February 2012. Powerpoint leaked to Action on Smoking and Health, 2013.

53. Philip Morris International, UK Corporate Affairs Update March 2012. Powerpoint leaked to Action on Smoking and Health, 2013.

54. Evans-Reeves KA, Hatchard JL, Gilmore AB. 'It will harm business and increase illicit trade': an evaluation of the relevance, quality and transparency of evidence submitted by Transnational Tobacco Companies to the UK Consultation on standardised packaging 2012. Tob Control 2015;24(e2):e168-77.

55. Hatchard JL, Fooks GJ, Evans-Reeves KA, et al. A critical evaluation of the volume, relevance and quality of evidence submitted by the tobacco industry to oppose standardised packaging of tobacco products. BMJ Open 2014;4:e003757.

56. Ulucanlar S, Fooks GJ, Hatchard JL, et al. Representation and misrepresentation of scientific evidence in contemporary tobacco regulation: a review of tobacco industry submissions to the UK government consultation on standardised packaging. PLoS Med 2014;11:e1001629.
57. Savell E, Gilmore AB, Fooks G. How does the tobacco industry attempt to influence marketing regulations? A systematic review. PLOS ONE 2014;9:e87389.

58. TobaccoTactics. Plain packaging in the UK: TCRG Research on Policy Opposition 2011-2013. 2016. http://tobaccotactics.org/index. php/Plain_packaging_in_the_UK:_TCRG_Research_on_Policy_ Opposition 2011-2013

59. Lincoln Y, Guba E. Naturalistic inquiry. Newbury Park, CA: Sage, 1985.

60. TobaccoTactics. Lynton Crosby 2014 (updated 6 November 2014). http://www.tobaccotactics.org/index.php/Lynton_Crosby

61. Philip Morris International. Standardised tobacco packaging will harm public health and cost UK taxpayers billions: A response to the Department of Health consultation on standardised packaging of tobacco products. 9 August 2012.

62. Philip Morris employee (name redacted). FW: Meeting follow up21 June 2012-Email to Intellectual Property Office official (name redacted). 25 June 2012. Intellectual Property Office FOI Reference FOI/2014/430. https://www.gov.uk/government/publications/ standardised-packaging-of-tobacco-products

63. Crosby L. IP issues and plain packaging email to Lord Marland Parliamentary Under Secretary for Intellectual Property. 1 November 2012. Intellectual Property Office FOI Reference FOI/ 2014/430. https://www.gov.uk/government/publications/ standardised-packaging-of-tobacco-products

64. TobaccoTactics. Hands Off Our Packs 2014 (updated 23 October 2014). http://www.tobaccotactics.org/index.php/Hands_Off_Our_ Packs (accessed Jun 2015)

65. Tobacco Reporter. Rousing start to Forest's anti-plain packaging campaign Online 2012 (updated 28 February 2012). http://www. forestonline.org/news-comment/headlines/

rousing-start-forests-anti-plain-packaging-campaign/ (accessed Feb 2016).

66. Hands Off Our Packs. Nannytown YouTube2012 (updated 5 March 2012). https://www.youtube.com/watch?v=azcDb2JneeQ (accessed Feb 2016).

67. Hands Off Our Packs. Interview with Andrew Turner of API Group Hands off our packs website2012 (updated 1 May 2012).

68. Hands Off Our Packs. Plain packaging-No Minister! YouTube2012 (updated 21 June 2012). https://www.youtube.com/watch? $\mathrm{v}=\mathrm{IQbJdCuedek}$ (accessed Feb 2016).

69. Common Sense Alliance. Plain packaging in Birmingham (3 short films) YouTube2012 (updated 12 September 2012). https://www. youtube.com/results?search_query=common+sense+alliance +birmingham+smokers (accessed Feb 2016).

70. British American Tobacco. Illegal cigarettes: Who's in control? YouTube2011 (updated 12 May 2011). https://www.youtube.com/ watch?v=|pFx7pLy2L0 (accessed Feb 2016).

71. British American Tobacco. Illegal cigarettes: This is the man YouTube2011 (updated 27 October 2011). https://www.youtube. com/watch?v=1NSgPzYJzcs (accessed Feb 2016)

72. Imperial Tobacco. Britain-2020 Vision? YouTube: Hands Off Our Packs; 2012 (updated 1 May 2012). https://www.youtube.com watch? $\mathrm{v}=\mathrm{q} 3 \mathrm{hCYS9qc3c}$ (accessed Feb 2016).

73. Mardle P. JTI launches campaign against plain tobacco packaging. UK: Mark Allen Business and Leisure, 2013 (updated 10 April 2013). http://www.printweek.com/print-week/news/1136368/ jti-launches-campaign-plain-tobacco-packaging (accessed Feb 2016).

74. Japan Tobacco International. First JTI campaign around "Plain" cigarette packs: ads question process in the UK Department of Health consultation. UK, 2012 (updated 6 July 2012). http://www.jti. $\mathrm{com} / \mathrm{media} /$ news-releases/first-jti-campaign-around-plain-cigarettepacks/ (accessed Feb 2016).

75. TobaccoTactics. Plain packaging opposition in the UK. 2013 (accessed Sept 2016). http://www.tobaccotactics.org/index.php/ Plain Packaging Opposition in the UK: 2012 Consultation

76. Japan Tobacco International. We couldn't have put it better ourselves. The Telegraph 8 April 2013.

77. Advertising Standards Authority. ASA Adjudication on Gallaher Ltd t/a JTI-3 rulings 2013 and 2014 (updated 7 January 2015). (accessed Sept 2016). "http://web.archive.org/web/ 20150110051232/http:/www.asa.org.uk/Rulings/Adjudications/ 2015/1/Gallaher-Ltd/SHP_ADJ 228477.aspx?” V “.V-

UiLvkrLIU"http://web.archive.org/web/20150110051232/http://www. asa.org.uk/Rulings/Adjudications/2015/1/Gallaher-Ltd/SHP_ADJ_ 228477.aspx?\#.V-UiLvkrLIU.

78. TobaccoTactics. Plain packaging opposition in the UK. 2013 (accessed Sept 2016). http://www.tobaccotactics.org/index.php/ Plain_Packaging_Opposition_in_the_UK:_2012_Consultation 
79. Association of Convenience Stores. Consultation on standardised tobacco packaging. Responsible retailing webinar; 24 April 2012. 2012. http://www.acs.org.uk

80. Lenane J. Say no to plain packs. National Federation of Retail Newsagents, 9 April 2013.

81. Markenverband. Plain packaging —unit packaging for food and beverage as an instrument of consumer protection? Frankfurt, 2012 (updated 28 June 2012). http://www.markenverband.de/ veranstaltungen/testoberordner/veranst2012/seminar-plainpackaging (accessed Feb 2016).

82. Asian Trader Magazine and Imperial Tobacco. WARNING Plain packaging: Bad for Business Good for Criminals. The House Magazine 2012

83. Scottish Wholesale Association. Plain nonsense. 2012. (accessed Sept 2016) http://web.archive.org/web/20120707092316/http://www scottishwholesale.co.uk/plain-nonsense.

84. Scottish Wholesale Association. Plain packaging advert. Holyrood Magazine. Imperial Tobacco Group. 2012

85. Hands Off Our Packs. Say no to plain packaging. 2012 (accessed Sept 2016). http://web.archive.org/web/20160409214833/http:// www.handsoffourpacks.com

86. Forest. Say No To Plain Packs. 2013. http://web.archive.org/web/ 20160408053452/http://www.no2plainpacks.org/about/ (accessed Feb 2016)

87. Clark S. Forest's Hands Off Our Packs petition letter sent to Tobacco Programme Manager UK Department of Health. 30 August 2012. Department of Health No Reference - FOI Date 19 November 2012. https://www.gov.uk/government/publications/dhfoi-release-correspondence-between-dh-and-tobaccomanufacturers-and-tobacco-trade-bodies-2.

88. Basham P. Monkey see, monkey smoke. Spiked. 24 April 2012. "http://web.archive.org/web/20160818015654/http://www. spiked-online.com/newsite/article/12374" VI ". VouVKbaLSUk"http://web.archive.org/web/20160818015654/ http://www.spiked-online.com/newsite/article/12374\# VouVKbaLSUk (accessed Sept 2016).

89. Progressive Vision. Progressive Vision backs Hands Off Our Packs! 7 February 2012.

90. Freedom Association joins campaign against plain tobacco packaging. 17 April 2012. http://web.archive.org/web/ 20160923131230/http://www.talkingretail.com/category-news/ supermarket/freedom-association-joins-campaign-against-plaintobacco-packaging/ (accessed Sept 2016).

91. Harbutt A. Angela Harbutt joins the fight against plain packaging on tobacco. 6 February 2012. http://web.archive.org/web/ 20160415210335/http://www.liberal-vision.org/2012/02/06/angelaharbutt-joins-the-fight-against-plain-packaging-on-tobacco/ (accessed Sept 2016).

92. Freedom2Choose. A quarter of a million against plain packaging. 8 August 2012. http://web.archive.org/web/20160923131641/http:// freedom2choose.info/news_viewer.php?id=1373 (accessed Sept 2016).

93. They Work For You. Register of Members Interests Theyworkforyou.com2012-4. Theyworkforyou.com (accessed Nov 2015).

94. UK Government. Her Majesty's Treasury documents that mention standardised or plain packaging of tobacco products FOI Release. 2014 (updated October 2014). https://www.gov.uk/government/ publications/hmt-documents-that-mention-standardised-or-plainpackaging-of-tobacco-products (accessed February 2016).

95. Department of Health. Note of meeting: Japan Tobacco International and Department of Health. Department of Health, 2013. FOI Reference DE775233 https://www.gov.uk/government/ publications/proposals-to-introduce-standardised-tobaccopackaging-de775233

96. Department of Health. Note of meeting: British American Tobacco and Department of Health-impact assessment on standardised packaging of tobacco. Department of Health, 2013. FOI Reference DE775233 https://www.gov.uk/government/publications/proposalsto-introduce-standardised-tobacco-packaging-de775233

97. Department of Health. Note of meeting Imperial Tobacco and Department of Health. Department of Health, 2013. FOI reference DE766508 https://www.gov.uk/government/publications/meetingsbetween-department-of-health-and-tobacco-companies-de766508

98. Department of Health. Note of meeting-Philip Morris International and Department of Health: impact assessment for standardised packaging of tobacco products. Department of Health, 2013. FOI Reference DE775233 https://www.gov.uk/government/publications/ proposals-to-introduce-standardised-tobacco-packaging-de775233

99. Intellectual Property Office. Marks and Design Forum minutes. 6 March 2013. Intellectual Property Office FOI reference FOI/2014/
430, released 11 August 2014. https://www.gov.uk/government/ publications/standardised-packaging-of-tobacco-products

100. Department of Health. Note of meeting on standardised packaging between DH and representatives of API Group, Weidenhammer Group, Payne and Parkside Flexibles. 21 March 2013. Department of Health FOI Reference DE00000918014, released 27 February 2015

101. API Group C, Weidenhammer, Payne, Parkside, Iggesund, Benkert, British Brands Group. Packaging as a barrier to trade in counterfeit/illicit goods: ref. plain packaging of tobacco products. 2013. Department of Health FOI Reference DE00000918014, released 27 February 2015.

102. Shrimpton D. Illegal tobacco on the increase. Independent Retail News 3 May 2013

103. Japan Tobacco International. The billion pound drop: The impact of tobacco smuggling and cross-border shopping in the UK. UK: JTI. com; October 2012. http://www.jti.com/files/2413/5220/4070/The Billion Pound Drop website version.pdf (accessed Sept 2016).

104. Hatchard J. Interview with a representative of a Tobacco Control non-governmental organisation. July 2013

105. Doward J. How Marlboro money paid for Common launch of tobacco study (January 2013), 26 April 2014. http://www. theguardian.com/business/2014/apr/26/marlboro-tobacco-keith-vazplain-packaging (accessed Sept 2016)

106. Transcrime. Plain packaging and illicit trade in the UK: Study on the risks of illicit trade in tobacco products as unintended consequences of the introduction of plain packaging in the UK. Joint Research Centre on Transnational Crime. May 2012. http:// www.transcrime.it/wp-content/uploads/2013/11/Transcrime-Plain packaging_and_illicit_trade_in_the_UK1.pdf (accessed Sept 2016).

107. Tobacco Retailers' Alliance. Newsletter: Party Conference Special. TRA website. November 2011.

108. Littlewood M. Speech to UKIP Conference: Mark Littlewood Director General Institute of Economic Affairs. 20 September 2013. http://web.archive.org/web/20160916135704/https://iea.org.uk/inthe-media/press-release/speech-to-ukip-conference-marklittlewood-director-general-institute-of-e (accessed Sept 2016).

109. TobaccoTactics. Corporate political advertising on plain packaging 2014 (updated 30 September 2014). http://www.tobaccotactics.org/ index.php/Corporate_Political_Advertising_on_Plain_Packaging (accessed Jun 2015).

110. Asian Media and Marketing Group (Asian Trader Magazine). Letter about standardised tobacco packaging (CEBR research) to $\mathrm{Mr}$ George Osborne MP, Chancellor of the Exchequer. 12 April 2013. HM Treasury No FOI Reference - released 27 October 2014. https://www.gov.uk/government/publications/hmt-documents-thatmention-standardised-or-plain-packaging-of-tobacco-products.

111. Chairman of the National Asian Business Association. Letter about standardised packaging (CEBR research) to Mr Sajid Javid MP Economic Secretary to the Treasury. May 2013. HM Treasury No FOI Reference - released 27 October 2014. https://www.gov.uk government/publications/hmt-documents-that-mentionstandardised-or-plain-packaging-of-tobacco-products.

112. Anti-Counterfeiting Group. ACG follow up from Alliance meeting standardised packaging for tobacco products-Department of Health consultation email to Andrew Layton of the Intellectual Property Office. 22 March 2013. Intellectual Property Office FOI reference FOl/2014/430, released 11 August 2014. https://www. gov.uk/government/publications/standardised-packaging-oftobacco-products.

113. British Brands Group (Name redacted). Standardised "plain" packaging-illicit trade implications email to Intellectual Property Office officials (including Andrew Layton). 22 March 2013. Intellectual Property Office FOI reference FOI/2014/430, released 11 August 2014. https://www.gov.uk/government/publications/ standardised-packaging-of-tobacco-products.

114. Association des Practiciens du Droit des Marques et des Modeles. APRAM's submission to the consultation on "plain packaging for tobacco products" sent to John Alty, Intellectual Property Office, UK. 9 July 2012. Intellectual Property Office FOI reference FOI/ 2014/430, released 11 August 2014. https://www.gov.uk/government/ publications/standardised-packaging-of-tobacco-products.

115. Secretary General Imported Tobacco Products Advisory Council. Standardised packaging of tobacco products sent to Mr Sajid Javid MP, Economic Secretary to the Treasury. 24 April 2013. HM Treasury No FOI Reference - released 27 October 2014. https:// www.gov.uk/government/publications/hmt-documents-that-mentionstandardised-or-plain-packaging-of-tobacco-products.

116. Confederation of British Industry. Letter regarding standardised packaging of tobacco products sent to Andrew Lansley, Department of Health, John Alty, Intellectual Property Office \& 
Mark Prisk, Department for Business Innovation and Skills. 11 July 2012. Intellectual Property Office FOI reference FOI/2014/430, released 11 August 2014. https://www.gov.uk/government/ publications/standardised-packaging-of-tobacco-products.

117. Chairman Petrol Retailers' Association. Letter about standardised tobacco packaging (CEBR research) sent to Mr Sajid Javid MP, Economic Secretary to the Treasury. 22 April 2013. HM Treasury No FOI Reference - released 27 October 2014. https://www.gov.uk/ government/publications/hmt-documents-that-mentionstandardised-or-plain-packaging-of-tobacco-products.

118. Khonat S. Consultation on standardised packaging of tobacco products sent to Department of Health (Unnamed recipient); cc. Mark Prisk (Minister of State for Business and Enterprise, Department for Business Innovation and Skills). 25 May 2012. Department of Health FOI Reference 719739, released 13 September 2012. https://www.gov.uk/government/publications/dhfoi-release-correspondence-about-the-government-s-consultationon-the-packaging-of-tobacco-products-2.

119. Clark S. Andrew Lansley: 'Supporter of Plain Packs' sent to Department of Health (unnamed recipient). 12 July 2012. Department of Health FOI Reference 719739, released 13 September 2012. https://www.gov.uk/government/publications/dhfoi-release-correspondence-about-the-government-s-consultationon-the-packaging-of-tobacco-products-2.

120. Head of Campaigns Hands Off Our Packs. Untitled letter sent to Consultations Coordinator, Department of Health. 25 July 2012. Department of Health FOI reference 734767. https://www.gov.uk/ government/publications/dh-foi-release-correspondence-regardingtobacco-control-and-packaging.

121. Paisley I MP and 50 parliamentary colleagues. Letter regarding standardised tobacco packaging sent to Andrew Lansley UK Minister for Health. 11 July 2012. Freedom of Information request. UK: Department of Health, 2012.

122. Paisley I and 50 colleagues. Letter regarding standardised tobacco packaging sent to Jeremy Hunt, MP, Minister for Health. 12 September 2012. Freedom of Information request. UK: Department of Health, 2012.

123. Paisley I and 73 colleagues. Letter regarding standardised tobacco packaging sent to Jeremy Hunt, MP, Minister for Health. 8 January 2013. Freedom of Information request. Department of Health, 2013

124. Johnson P. Trade marks without a brand: the proposals on "plain packaging" of tobacco products. Eur Intellect Property Rev 2012;34:461-70.

125. Sheridan P. Plans for plain packaging of cigarettes are a charter for organised crime and a danger to our children. 22 June 2012. http://web.archive.org/web/20160325024735/http://www.dailymail. co.uk/debate/article-2163227/Plans-plain-packaging-cigarettescharter-organised-crime-danger-children.html (accessed Sept 2016).

126. Sheridan P. Plain packaging will create a fertile ground for tobacco smuggling. 2 December 2012. http://web.archive.org/web/ 20150122231807/http://www.huffingtonpost.co.uk/peter-sheridan/ plain-tobacco-packaging-will-crea_b_2224498.html (accessed Sept 2016).

127. Sheridan P. Interview on Radio Foyle. 30 November 2012.

128. Ramm R. Government plans for plain packaging will boost illicit trade. 2 July 2012. http://web.archive.org/web/20160809202120/ http://www.huffingtonpost.co.uk/roy-ramm/plain-cigarette-packaginggovernment-plans-for-plai_b_1637528.html (accessed Sept 2016).

129. TobaccoTactics. Peter Sheridan 2015 (updated 13 January 2015). http://www.tobaccotactics.org/index.php/Peter_Sheridan (accessed Jul 2015).

130. Retail Motor Industry. PRA deeply concerned by new evidence on the negative impact of plain packaging in Australia UK. 1 October 2013. http://web.archive.org/web/20160926084046/http://www.rmif. co.uk/press-room/press-releases/pra-deeply-concerned-by-newevidence-on-the-negative-impact-of-plain-packaging-in-australia-0110-13/?y=2013\&m=10 (accessed Sept 2016).

131. Retail Motor Industry. Thousands of small, independent petrol stations call on the government to scrap 'onerous and illconsidered' regulation Retail Motor Industry. 27 November 2012. http://web. archive.org/web/20160824110010/http://www.rmif.co.uk/press$\mathrm{room} /$ press-releases/thousands-of-small-independent-petrolstations-call-on-the-government-to-scrap-onerous-and-illconsidered-regulation-27-11-12/?y=2012\&m=11 (accessed Sept 2016).

132. Rural Shops Alliance. Plain tobacco packs would cost retailers tens of million pounds a year. RSA, 10 October 2012.

133. Rural Shops Alliance. Selling tobacco in plain packaging would take longer-the Rural Shops Alliance provides conclusive evidence. RSA, 13 August 2012.
134. Halogen. Illicit tobacco trade endemic in Scotland. Edinburgh, 21 November 2013. http://web.archive.org/save/http://www. halogencomms.com/illicit-tobacco-trade-endemic-in-scotland/ (accessed Sept 2016).

135. British American Tobacco. New Deloitte report reveals that packaging laws have not directly reduced smoking. 4 May 2011 http://web.archive.org/web/20150301194139/http://www.bat.com/ group/sites/UK_9D9KCY.nsf/vwPagesWebLive/DO8GHFEN? opendocument\&SKN=1 (accessed Sept 2016).

136. Japan Tobacco International. DH meeting minutes with JTI changes. 15 April 2013. Department of Health FOI Reference DE833710. https://www.gov.uk/government/uploads/system/ uploads/attachment data/file/279731/DE833710 3 _.pdf

137. Philip Morris International. Letter from Martin Inkster PMI to Anna Soubry MP in the Department of Health. 29 January 2013. Department of Health FOI Reference 796546. https://www.gov.uk government/publications/correspondence-between-philip-morrisinternationalphilip-morris-ltd-and-dh.

138. Philip Morris International. Letter from Martin Inkster PMI to the Department of Health. 25 March 2013. Department of Health FOI Reference 796546. https://www.gov.uk/government/publications/ correspondence-between-philip-morris-internationalphilip-morris-ltdand-dh.

139. Philip Morris International. Letter from Martin Inkster PMI to Anna Soubry MP in the Department of Health. 17 April 2013. Department of Health FOI Reference 796546. https://www.gov.uk/government/ publications/correspondence-between-philip-morrisinternationalphilip-morris-Itd-and-dh

140. Soubry A. Tobacco packaging - statement to the House of Commons. Hansard. 12 July 2013 (Column 679). http://web. archive.org/web/20160518013317/http://www.publications. parliament.uk/pa/cm201314/cmhansrd/cm130712/debtext/1307120001.htm (accessed Sept 2016).

141. Ellison J. Written ministerial statement: Department of Healthtobacco control update. UK: Hansard. 28 November 2013. http:// web.archive.org/save/_embed/http://www.parliament.uk/documents/ commons-vote-office/November-2013/28\%20November/7-HealthTobaccoControl.pdf (accessed Sept 2016).

142. Soubry A. Tobacco packaging parliamentary business. Hansard. 11 December 2012: Column 285W-286W. http://web.archive.org/ web/20160926090205/http://www.publications.parliament.uk/pa/ cm201213/cmhansrd/cm121211/text/121211w0005.htm (accessed Sept 2016).

143. Soubry A. Tobacco: packaging parliamentary business. Hansard. 10 September 2012: Column 115W. "http://web.archive.org/web/ 20150930221620/http://www.publications.parliament.uk/pa/ cm201213/cmhansrd/cm120910/text/120910w0004.htm" V “12091037001997"http://web.archive.org/web/20150930221620/ http://www.publications.parliament.uk/pa/cm201213/cmhansrd/ cm120910/text/120910w0004.htm\#12091037001997 (accessed Sept 2016)

144. Soubry A. Tobacco: packaging parliamentary business. Hansard, 29 January 2013: Column 719W2013. "http://web.archive.org/web/ 20140505091351/http://www.publications.parliament.uk/pa/ $\mathrm{cm} 201213 / \mathrm{cmhansrd} / \mathrm{cm} 130129 / \mathrm{text} / 130129$ w0002.htm" "13012985001344"http://web.archive.org/web/20140505091351/ http://www.publications.parliament.uk/pa/cm201213/cmhansrd/ cm130129/text/130129w0002.htm\#13012985001344 (accessed Sept 2016)

145. Peeters S, Costa H, Stuckler D, et al. The revision of the 2014 European tobacco products directive: an analysis of the tobacco industry's attempts to 'break the health silo'. Tob Control 2016;25:108-17.

146. Fooks GJ, Gilmore AB. Corporate philanthropy, political influence, and health policy. PLOS ONE 2013;8:e80864.

147. Schattschneider EE. The Semisovereign people: a realist's view of democracy in America. New York: Holt, Rinehart and Winston, 1960

148. Millson S. Letter from Group Head of Corporate Affairs for BAT to Deborah Arnott. ASH, 20 May 2013.

149. Bernhagen P. The political power of business: structure and information in public policymaking: Routledge research in comparative politics. Abingdon, NY: Routledge, 2007.

150. Farnsworth K. Corporate power and social policy in a global economy: British welfare under the influence. Bristol: Policy Press, 2004

151. Farnsworth $\mathrm{K}$, Farnsworth $\mathrm{C}$. The business-social policy nexus: corporate power and corporate inputs into social policy. J Soc Policy 2006;35:473-94.

152. Visuality. The effects of standardised packaging on retail service in the UK. Rural Shops Alliance, September 2012. 
153. Deloitte. Alliance of Australian retailers: potential impact on retailers from the introduction of plain tobacco packaging. Australia. February 2011.

154. Deloitte. Alliance of Australian retailers: plain packaging and channel shift. Australia. June 2011. http://web.archive.org/web/ 20130502153600/https://www.australianretailers.com.au/ downloads/pdf/deloitte/Potential_impact_of_channel_shift.pdf (accessed Sept 2016).

155. McCombs M. Setting the agenda: the mass media and public opinion. Hoboken, NJ: John Wily and Sons, 2004.

156. Fooks GJ, Gilmore AB, Smith KE, et al. Corporate social responsibility and access to policy élites: An analysis of tobacco industry documents. PLoS Med 2011;8:e1001076.

157. Costa $H$, Gilmore $A B$, Peeters $S$, et al. Quantifying the influence of tobacco industry on EU governance: automated content analysis of the EU Tobacco Products Directive. Tob Control 2014;23:473-8.

158. Forest. Stop the nonsense say critics of plain packaging. 2015 (updated 4 March 2015). http://web.archive.org/web/ 20150309011558/http://www.forestonline.org/news-comment/ headlines/stop-nonsense-say-critics-plain-packaging/ (accessed Ju 2016).

159. UK Government. Children and Families Act 2014 Chapter 6. London: UK Government, 2014. http://www.legislation.gov.uk/ ukpga/2014/6/contents/enacted (accessed Feb 2016).

160. YouGov. Opinion poll on standardised packaging conducted for Action on Smoking and Health. January-March 2013. Smokefree Action Coalition. http://www.smokefreeaction.org.uk/files/docs/ PPregs20150309.pdf (accessed Feb 2016).

161. YouGov. Standardised packaging survey. Findings published by Action on Smoking and Health: Public support plain standardised packaging cigarettes. 10 August 2012. http://web.archive.org/web/ 20161004070058/http://ash.org.uk/media-and-news/press-releases media-and-news/public-support-plain-standardised-packaging-ofcigarettes/ (accessed Sept 2016).
162. Smith KE, Fooks G, Collin J, et al. "Working the System"-British American Tobacco's influence on the European Union Treaty and its implications for policy: an analysis of internal tobacco industry documents. PLoS Med 2010;7:e1000202.

163. Pralle S. Venue shopping, political strategy, and policy change: the internationalization of Canadian forest, advocacy. J Public Policy 2003:233-60.

164. Pralle S. Branching out, digging in: environmental advocacy and agenda setting. Washington DC: Georgetown University Press, 2006

165. Pralle S. Agenda-setting and climate change. Environ Polit 2009;18:781-99.

166. Smith K, Savell E, Gilmore A. What is known about tobacco industry efforts to influence tobacco tax? A systematic review of empirical studies. Tob Control 2013;22:144-53.

167. Schattschneider $\mathrm{E}$. The semi-sovereign people: a realist's view of democracy. New York: Rinehart and Winston, 1960.

168. Chapman S, Freeman B. Removing the Emperor's clothes: Australia and tobacco plain packaging. Sydney: Sydney University Press, 2014

169. Information Rights Manager - Intellectual Property Office. RE: FOI Request sent to Jenny Hatchard. Freedom of Information request response. 11 August 2014.

170. Information Rights Unit HM Treasury. Freedom of Information Act 2000: Standardised packaging sent to Jenny Hatchard. Freedom of Information request. HM Treasury, 2014.

171. Clements P, Information Commissioner's Office. Letter concluding complaint regarding the Regulatory Policy Committee sent to Dr Jenny Hatchard. Cheshire, UK, 2014

172. Gilmore AB, Britton J, McKee M. BBC must ensure commentators' tobacco industry links are made public. Lancet 2014;383:952-3.

173. TobaccoTactics. Welcome to TobaccoTactics. 2016 (updated 3 August 2016). http://www.tobaccotactics.org/index.php/Main_Page (accessed Aug 2016).

174. World Health Organisation. Tobacco industry monitoring database. Geneva, 2016. http://www.who.int/tobacco/industry/monitoring/en/ (accessed Aug 2016). 
Correction: Standardised tobacco packaging: a health policy case study of corporate conflict expansion and adaptation

Hatchard JL, Fooks GJ, Gilmore AB. Standardised tobacco packaging: a health policy case study of corporate conflict expansion and adaptation. BMJ Open 2016;6:e12634. On page 8 , a sentence reads: 'For example, in public communications former police officers did not declare membership of the Common Sense Alliance (a FOREST offshoot).' The Common Sense Alliance is not an offshoot of FOREST. It was supported by British American Tobacco among other organisations. The phrase in brackets '(a FOREST offshoot)' should be omitted.

Open Access This is an Open Access article distributed in accordance with the terms of the Creative Commons Attribution (CC BY 4.0) license, which permits others to distribute, remix, adapt and build upon this work, for commercial use, provided the original work is properly cited. See: http://creativecommons.org/licenses/by/4.0/

BMJ Open 2016;6:e012634corr1. doi:10.1136/bmjopen-2016-012634corr1

CrossMark 